\title{
ARAB SUNNI DAN IRAN SYIAH KONTEMPORER : KONFLIK ATAU PERSAINGAN?
}

\author{
Muhammad Mutawali \\ UIN Mataram \\ Email: muh.mutawaliuinmataram.ac.id
}

\begin{abstract}
This article explains the problems that occur between Sunni and Shi'a schools starting after the death of the Prophet Muhammad. History records that there has been a prolonged conflict which is motivated by political conflict, ideological conflict, paradigm conflict and thought which are factors that hamper reconciliation efforts, given the existence of very painful past events between the two streams. For Shiites, the story of discrimination experienced by Ali ibn Abi Talib until the tragedy of Karbala with the killing of Husein the Prophet's grandson and the story of the Ahlul Bait pain became a very painful social memory. For Sunnis, insults, insults, curses and disbelief aimed at the main Companions of Abubakar, Umar, Uthman and the wife of Rasulullah Aisyah Al-Kubra became the main cause of disharmony in relations between Sunnis and Shiites. Disharmonization has also impacted on relations between countries in the Middle East who competed for influence in the Gulf until now after the Arab Spring.
\end{abstract}

\section{Keywords: Sunni, Shiite, Conflict, Competition, The Arab Spring}

\begin{abstract}
ABSTRAK
Artikel ini menjelaskan problematika yang terjadi antara aliran Sunni dan Syiah dimulai pasca meninggalnya Nabi Muhammad SAW. Sejarah mencatat bahwa telah terjadi sebuah konflik berkepanjangan yang dilatarbelakangi oleh konflik politik, konflik ideologi, konflik paradigma dan pemikiran yang menjadi faktor penghambat upaya rekonsiliasi, mengingat adanya peristiwa masa lampau yang sangat menyakitkan antara dua aliran tersebut. Bagi Syiah, kisah diskriminasi yang dialami oleh Ali bin Abi Thalib hingga tragedi Karbala dengan terbunuhnya Husein cucu Rasulullah dan kisah kepedihan Ahlul Bait menjadi ingatan sosial yang sangat menyakitkan. Bagi Sunni, penghinaan, cacian, makian dan pengkafiran yang ditujukan kepada para Sahabat utama Abubakar, Umar, Utsman dan Istri Rasulullah Aisyah Al-Kubra menjadi sebab utama disharmonisasi hubungan antara Sunni dan Syiah. Disharmonisasi tersebut berdampak pula pada hubungan antara negara-negara di Timur Tengah yang saling bersaing merebut pengaruh di Teluk hingga kini pasca the Arab Spring.
\end{abstract}

Kata kunci: Sunni, Syiah, Konflik, Persaingan, The Arab Spring 


\section{PENDAHULUAN}

Kajian tentang aliran Sunni atau Ahlu Sunnah dan Syiah tidak akan berakhir hingga dunia ini runtuh, begitu juga pertentangan di antara keduanya tidak akan ada ujungnya. Kalangan Ahlu Sunnah merefleksikan dirinya sebagai aliran yang mengikuti ajaran dan Sunnah Nabi yang diteruskan oleh para sahabatnya. Sementara Syiah merepresentasikan diri sebagai pengikut Nabi Muhammad melalui jalur Ahlul Bait, keturunan Nabi melalui Ali bin Abi Thalib dan diteruskan oleh keturunannya.

Secara historis, Kemunculan dua aliran ini bermula dari permasalahan politik yaitu masalah kekhalifahan/khilafah yaitu puncak kepemimpinan (al-Imamah al-kubra). Dinamakan dengan khalifah, karena yang memegang jabatan ini merupakan pemimpin tertinggi kaum muslimin dan pengganti Nabi dalam urusan kehidupan di dunia. Pertentangan ini bermula dari permasalahan politik, siapa pemegang tampuk pimpinan ummat sepeninggal Nabi yang akhirnya berdampak pada permasalahan Teologi, saling kafir mengkafirkan dan saling klaim akan kebenaran, maka umat Islam tercerai berai.

Krisis politik yang berakhir pada pertarungan wacana dan kepentingan melatarbelakangi lahirnya aliran-aliran dalam Islam, seperti syiah, khawarij, murjiah, mutazilah, Sunni dan yang lainnya. Namun krisis politik tersebut bukanlah satu-satunya penyebab lahirnya aliran-aliran itu. Menurut Abid Al-Jabiri, jauh sebelum persoalan politik tersebut mengemuka, telah terbangun kerangka pemikiran yang memungkinkan terjadinya varian kelompok politik dan pemikiran di kalangan umat Islam. Situasi krisis politik pasca Nabi hanyalah sebuah momentum yang memantik munculnya perbedaan tersebut, benih dan kerangka yang sudah tersedia sebelumnya.

Asumsi Al-Jabiri tersebut bisa dibuktikan bila melihat dinamika aliran teologi dalam Islam pada rentang waktu kemudian, baik Syiah maupun Sunni yang terus berkembang dari periode ke periode tidak lagi berbentuk sebagai aliran politik an sich, tetapi juga aliran pemikiran yang memiliki corak dan identitas yang berbeda antara satu sama lainnya. Kalau hanya persoalan politik pasti keberlangsungannya hanya sementara dan hanya sebatas perebutan kepentingan politik. Namun karena yang memicu munculnya aliran tersebut adalah kerangka pemikiran (paradigma), maka aliran tersebut pun abadi melampaui konteks krisis politik di Arab pasca kepemimpinan Nabi Muhammad SAW. ${ }^{1}$

Ahlu Sunnah-Syiah atau Sunni-Syiah merupakan dua kelompok mainstream dalam dunia pemikiran dan gerakan Islam dari masa klasik hingga kontemporer yang sampai kini

${ }^{1}$ Zainal Abidin, Imamah dan Implikasinya dalam Kehidupan Sosial (Jakarta: Balitbang Kemenag RI, 2012), h. 5-6. 
menarik untuk ditelaah, yang kemudian memunculkan pertanyaan apakah pertentangan keduanya merupakan bentuk sebuah konflik ataukah persaingan? tulisan ini mencoba atau setidaknya berusaha mencari sedikit jawaban dari pertanyaan tersebut.

\section{Sunni dan Syiah}

Sunnah secara harfiah berarti tradisi. Ahlu Sunnah berarti orang-orang yang secara konsisten mengikuti tradisi Nabi Muhammad SAW, dalam hal ini adalah tradisi Nabi dalam tuntunan lisan maupun amalan beliau serta sahabat mulia beliau. ${ }^{2}$ Ahlu Sunnah (wal Jamąah) menjadi istilah khusus yang ditujukan kepada kelompok yang menjadi pengikut dan yang berpegang teguh kepada Sunnah dan menjadi mainstream (arus utama). Term ini juga digunakan untuk menunjukkan siapa saja yang mengikuti salah satu Imam Mazhab fiqh yang popular (seperti syafi'i, Hanafi, Maliki, Hambali). ${ }^{3}$

Ahlu Sunnah juga ditujukan kepada kelompok yang menerima kepemimpinan Abubakar sebagai Khalifah/pemimpin agama dan pemimpin politik umat Islam setelah Nabi Muhammad meninggal dunia pada tahun $632 \mathrm{M}^{4}$ Pendapat lain diutarakan oleh Ira M. Lapidus dalam bukunya, bahwa umat Islam terpecah dalam memperebutkan kedudukan Khilafah. Muslim yang menerima suksesi Muawiyah dan serangkaian khalifah sesudahnya disebut Sunni. Sedang mereka yang bersikeras bahwa Ali adalah satu-satunya khalifah yang berhak dan bahwasanya hanya keturunannya yang berhak meneruskan dan menggantikannya disebut Syiah. ${ }^{5}$ Ada juga beberapa pakar yang menyatakan bahwa kelompok Ahlu Sunnah muncul sebagai reaksi atas paham Mutazilah, yang disebarkan oleh Washil bin Atha (w.131H/748M), dan yang sangat mengandalkan akal dalam memahami dan menjelaskan ajaran-ajaran Islam. ${ }^{6}$

Syiah secara etimologi berarti pengikut, pendukung, pembela, pencinta yang kesemuanya mengarah kepada makna dukungan kepada ide atau individu dan kelompok tertentu. $^{7}$ Ajaran Syiah berawal pada sebutan yang untuk pertama kalinya ditujukan kepada para pengikut Ali (Syiat Ali), pemimpin pertama pada masa hidup Nabi. ${ }^{8}$

${ }^{2}$ Quraish Shihab, Sunnah-Syi`ah, Bergandengan Tangan, Mungkinkah? Kajian atas Konsep Ajaran dan Pemikiran (Jakarta: Lentera Hati, 2007), h. 57.

${ }^{3}$ Asrar Mabrur Faza, Syi ah dalam Kitab Sunni (Medan: Perdana Publishing, 2015), h. 14.

${ }^{4}$ Nathan Gonzalez, The Sunni-Shia Conflict: Understanding Sectarian Violence in The Middle East (USA: Nortia Press, 1979), h. 4.

${ }^{5}$ Ira M. Lapidus, Sejarah Sosial Ummat Islam (Jakarta: Rajagrafindo Persada, 1999), h. 87.

${ }^{6}$ Quraish Shihab, Sunnah-Syi ah, Bergandengan tangan, mungkinkah? Kajian atas konsep ajaran dan pemikiran, h. 58.

${ }^{7}$ Quraish Shihab, Sunnah-Syi ah, Bergandengan Tangan, Mungkinkah? Kajian atas Konsep Ajaran dan Pemikiran, h. 60.

${ }^{8}$ Allamah MH. Thabaththaba`i, Shi ite Islam, Terj. (Jakarta: Pustaka Utama Grafiti, 1989), h. 37. 
Muhammad Jawad Maghniyah, seorang ulama beraliran Syiah memberikan definisi tentang kelompok Syiah sebagaimana yang dikutip M. Quraish Shihab dalam bukunya, bahwa mereka adalah kelompok yang meyakini bahwa Nabi Muhammad SAW. telah menetapkan dengan Ahlul Bait nash (pernyataan yang pasti) tentang khalifah (pengganti) beliau dengan menunjuk Imam Ali. Definisi ini sejalan dengan definisi yang dikemukakan oleh Ali Muhammad al-Jurjani, seorang Sunni beraliran Asyariyah yang dikutip juga oleh Quraish Shihab dalam bukunya, Syiah adalah mereka yang mengikuti Sayyidina Ali dan percaya bahwa beliau adalah imam sesudah Rasulullah SAW. dan percaya bahwa imamah tidak keluar dari beliau dan keturunannya. ${ }^{9}$

Lebih lanjut Quraish Shihab menyatakan bahwa benih Syiah muncul sejak masa Nabi Muhammad SAW atau paling tidak secara politis benihnya muncul saat wafatnya Nabi (pembaiatan Abubakar di Tsaqifah). Ketika itu keluarga Nabi dan sejumlah sahabat memandang bahwa Ali bin Abi Thalib lebih wajar dan lebih berhak menjadi khalifah Nabi daripada Abubakar. ${ }^{10}$ Mereka berpendapat bahwa banyak hadis Nabi dengan jelas menegaskan bahwa Ali telah dilindungi dari kesalahan dan dosa, baik dalam tindakan maupun perkataan dan Ali paling mengetahui tentang Islam dan hukum-hukumnya. ${ }^{11}$

Syiah adalah mazhab politik yang pertama lahir dalam Islam dan tampil pada akhir masa pemerintahan Utsman, kemudian tumbuh dan berkembang pada masa Ali. Kalangan Syiah sepakat bahwa Ali adalah khalifah pilihan Nabi dan Ali adalah orang yang paling utama di antara para Sahabat Nabi. Kalangan Syiah tidak bersikap sama dalam menetapkan posisi Ali dan keturunannya. Sebagian bersikap ekstrim dan sebagian lain bersikap moderat. Kelompok moderat terbatas hanya pada mengutamakan Ali atas semua sahabat, tidak mengkafirkan seseorang dan tidak mengkultuskan Ali hingga dipandang lebih utama dari semua manusia. $^{12}$

\section{Teologi Ahlu Sunnah dan Syiah}

\section{Teologi Syi'ah}

Seorang penulis Mesir, Ahmad Amin (w.1954) mencoba menyederhanakan ciri-ciri ekslusif Syi'ah menjadi empat prinsip utama, yaitu: 'ismah (ketakbercacatan Imam),

\footnotetext{
${ }^{9}$ Quraish Shihab, Sunnah-Syi`ah, Bergandengan tangan, mungkinkah? Kajian atas konsep ajaran dan pemikiran, h. 61 .

${ }^{10}$ Quraish Shihab, Sunnah-Syi ah, Bergandengan Tangan, Mungkinkah? Kajian atas Konsep Ajaran dan Pemikiran, h. 65-66.

${ }^{11}$ Allamah MH. Thabaththabài, Shi ite Islam, h. 38.

12 Muhammad Abu Zahrah, Aliran Politik dan Aqidah dalam Islam (Terj) (Jakarta: Gaya Media Pratama, 2011), h. 34-35.
} 
Mahdiisme (dalam Syi'ah Itsna Asyariah) yang mempercayai adanya dua belas Imam, Muhammad al-Mahdi al-Muntazhar adalah Imam yang kedua belas. Al-Muntazhar menghilang pada tahun $260 \mathrm{H}$. Syi'ah Itsna Asyariah meyakini bahwa suatu saat nanti Muhammad al-Mahdi al-Muntazhar (Imam Mahdi) akan kembali untuk menegakkan keadilan dan kebenaran kepada kaumnya. Paham inilah yang disebut dengan Mahdiisme); taqiyah (melindungi atau menuntun diri) bahwa taqiyyah adalah salah satu strategi gerakan politik Syi'ah dimana dalam konsep ini disebutkan bahwa di bawah kondisi yang mengancam keselamatan, seorang pengikut Syi'ah diperbolehkan untuk menyembunyikan identitas ke-Syi'ah-annya dan menampakkan sisi lain dari dirinya. Konsep ini muncul karena sarjana-sarjana Syi'ah menganggap bahwa Syi'ah dalam sejarah selalu menjadi objek persekusi kaum Sunni yang mayoritas dan pemilik kekuatan politik; dan raj'ah (kekembalian) Imam. ${ }^{13}$

Permasalahan yang paling membedakan antara Sunni dan Syiah adalah masalah Imamah. Doktrin imamah yang dianut Syiah bertitik tolak dari keyakinan kaum Syiah bahwa imam yang adil akan selalu diturunkan Allah SWT. ke persada bumi ini untuk membimbing umat manusia sesuai dengan ajaran-ajaran yang telah ditunjukkan-Nya. Imam pilihan-Nya itu mempunyai kualifikasi tertentu yang ditunjuk melalui wasiat Nabi-Nya dan selanjutnya dengan penunjukkan seorang imam terhadap penggantinya secara terus menerus sampai dengan imam yang ke-12. Imam menurut Syiah, diberi otoritas seperti halnya Rasulullah dalam menginterpretasikan esoteris wahyu dan memimpin kaum muslimin. ${ }^{14}$

Syiah meyakini bahwa imam memperoleh ilham ilahi dan terjaga dari dosa dan khilaf dan imam akan membawa kepada keselamatan. ${ }^{15}$

Syiah menegaskan bahwa kekhalifahan Islam dimana bimbingan esoteris dan kepemimpinan rohani merupakan unsur-unsur yang tak terpisahkan adalah milik Ali dan keturunannya. Mereka juga percaya bahwa menurut keterangan Nabi, imam Ahlul Bait berjumlah 12 orang dan berkeyakinan bahwa ajaran al-Qur'an adalah sah berlaku dan dilaksanakan setiap orang dan mesti dipelajari melalui bimbingan Ahlul Bait. ${ }^{16}$ Syiah percaya bahwa setelah Nabi wafat, kekhalifahan dan kekuasaan agama berada di tangan Ali.

${ }^{13}$ Ahmad Sahide, Konflik Syi'ah-Sunni Pasca-The Arab Spring (Jurnal Kawistara, 2013), Vol. 3 No. 3 , h. 229-230.

${ }^{14}$ Khoiruddin Nasution, Isu-isu Kontemporer Hukum Islam (Yogyakarta: Suka Press, 2007), h. 55.

${ }^{15}$ W. Montgomery Watt, The Majesty That was Islam, Terj. (Yogyakarta: Tiara Wacana Yogya, 1990), h. 69.

${ }^{16}$ Allamah MH. Thabaththaba i, Shi ite Islam, h. 87-89. 
Kepercayaan ini berpangkal pada pandangan tentang kedudukan dan tempat Ali dalam hubungan dengan Nabi, hubungan dengan kalangan terpilih di antara para sahabat maupun hubungan dengan kaum muslimin umumnya. ${ }^{17}$

Syiah dengan konsep imamahnya memberikan dampak yang signifikan bagi kelangsungannya dalam percaturan dan pertarungan ideologis khususnya di bidang politik. Bahkan masuk dalam diskursus pemerintahan secara konstan dan adanya doktrin iman kepada imam sebagai dimensi esoteris dalam akidah Syiah. ${ }^{18}$

\section{Teologi Sunni}

Doktrin utama Ahlu Sunnah atau Sunni adalah bahwa al-Qur'an bukanlah makhluk (tidak diciptakan) yang berbeda dan menentang doktrin Mutazilah yang menyatakan bahwa al-Qur'an adalah makhluk (diciptakan). Kepercayaan dan ideologi Sunni yang merujuk kepada ajaran masa awal Islam guna mengikuti Nabi Muhammad, para Sahabat dan para Tabiin. ${ }^{19}$

Menurut Muhammad Imarah, sebagaimana dikutip M. Quraish Shihab bahwa Sunni memperurutkan keutamaan khulafa ar-Rasyidin sesuai urutan masa kekuasaan mereka, mereka membaiat yang memegang tampuk kekuasaan baik penguasa yang taat maupun tidak, menolak revolusi dan pembangkangan sebagai cara untuk mengubah ketidakadilan. ${ }^{20}$

\section{Pemikiran Politik Sunni-Syiah}

Pada intinya, pemikiran politik Sunni sepakat bahwa pemerintahan adalah sesuatu yang niscaya demi memungkinkan manusia bekerja sama untuk meraih tujuan hidupnya yang sejati. Yakni suatu kehidupan yang baik berdasar Syariah yang pada gilirannya akan menghasilkan bagi mereka tempat yang baik di kehidupan akhirat. Akan tetapi, Sunni juga membatasi seorang khalifah atau pengganti Nabi Muhammad SAW bahwa mereka haruslah laki-laki dan dari keturunan suku Quraisy atau dari kelompok mereka. ${ }^{21}$

Bagi Syiah, bukti utama tentang sahnya Ali sebagai penerus Nabi adalah peristiwa Ghadir Khum. Ketika itu Nabi memilih Ali sebagai pepimpin umat (walayat_amah) dan

\footnotetext{
${ }^{17}$ Allamah MH. Thabaththaba`i, Shi ite Islam, h. 40.

${ }^{18}$ Zainal Abidin, Imamah dan Implikasinya dalam Kehidupan Sosial, h. 131.

${ }^{19}$ Joel L. Kraemer, Renaisans Islam (Bandung: Mizan, 2003), h.100.

${ }^{20}$ Quraish Shihab, Sunnah-Syi ah, Bergandengan Tangan, Mungkinkah? Kajian atas Konsep Ajaran dan Pemikiran, h. 59.

${ }^{21}$ Ahmad Sahide, Konflik Syi'ah-Sunni Pasca-The Arab Spring (Jurnal Kawistara, 2013), vol 3 No. 3 ,
} 
menjadikan Ali sebagai pelindung mereka (wali). ${ }^{22}$ Bagi Syiah isu terpenting bukanlah hukum dan mistisisme, melainkan loyalitas terhadap Ali dan penegasan bahwasanya hak khilafah hanya dapat berlangsung di tengah keluarga Ali. Pada abad ke-7 dan ke-8, isu tersebut mengarah kepada gerakan politis dalam bentuk perlawanan kepada Dinasti Umayyah dan Abbasiyyah. Loyalitas keluarga ini berkali-kali berusaha merebut khilafah. Kekalahannya dalam perebutan kekuasaan politik mengalihkan perhatian sejumlah tokoh Syiah dari aktivitas politik kepada aktivitas refleksi keagamaan. ${ }^{23}$

Setelah imam terakhir menghilang pada tahun 873 dan pada tahun 941 komunikasi secara langsung dengan imam (tersembunyi) telah berakhir. Hilangnya petunjuk ketuhanan dari sang imam benar-benar mengubah karakter keagamaan dan sosial kaum Syiah, mereka mulai melancarkan kebaktian massal untuk mengutuk Muawiyah sebagai musuh Ali, menjadikan hari kematian Husayn di karbala (asyura) sebagai hari raya berkabung, dan peringatan peristiwa Ghadir Khum. ${ }^{24}$

Dari aspek politik, Syiah lebih menekankan pada aspek keturunan Rasulullah yang dilegitimasi oleh Nash dan kemampuan keilmuan yang tinggi untuk memegang tampuk kepemimipinan bagi kaum muslimin. Syiah meyakini bahwa kepemimpinan adalah warisan secara turun-temurun dari Nabi dan tidak mengakomodir selain dari model penunjukan atau penetapan. $^{25}$

\section{Akar Konflik Sunni-Syiah}

Adapun akar konflik antara Sunni-Syiah adalah sama-sama saling memusuhi dan saling kafir-mengkafirkan. Sunni berpendapat bahwa Syiah adalah aliran yang sesat karna mengkafirkan Abubakar, Umar, Utsman dan Aisyah, dan menganggap bahwa Ali memiliki sifat ketuhanan sehingga dianggap sebagai tuhan. Demikian juga sebaliknya, Syiah berpendapat bahwa Sunni adalah musuh yang sebenarnya musuh karna membenci Ahlul Bait dan Sunni tidak mengakui adanya konsep imamah yang dianut oleh Syiah.

Menurut Joel L. Kraemer dalam bukunya Renaisans Islam bahwa akar konflik antara Sunni dan Syiah adalah adanya penolakan dari Syiah imamiyah terhadap hadis-hadis yang

${ }^{22}$ Allamah MH. Thabaththaba`i, Shi ite Islam, Terj, h. 38. Menurut kepercayaan syiah, ketika kembali dari Haji terakhir, dalam perjalanan dar mekkah ke madinah, di suatu padang yang bernama Ghadir Khum Nabi memilih Ali sebagai penggantinya di hadapan masa yang penuh sesak yang menyertai beliau. Orang syia merayakan ini sampai hari ini, sebagai suatu pesta keagamaan yang besar yang menandai saat Ali berhak menjadi khalifah diumumkan secara terbuka.

\footnotetext{
${ }^{23}$ Ira M. lapidus, Sejarah Sosial Ummat Islam (Jakarta: Rajagrafindo Persada, 1999), h. 177.

${ }^{24}$ Ira M. Lapidus, Sejarah Sosial Ummat Islam, h. 248-249.

${ }^{25}$ Zainal Abidin, Imamah dan Implikasinya dalam Kehidupan Sosial, h.134-135.
} 
diwariskan atau diriwayatkan berdasarkan otoritas sahabat-sahabat Nabi yang dipandang Sunni sebagai pihak yang otoritatif dan terhadap legitimasi dari ketiga khalifah pertama sebelum Ali. ${ }^{26}$

\section{Keruntuhan Dinasti Fathimiyah}

Dinasti fatimiyah (969-1171) mengklaim sebagai pemimpin Islam yang sebenarnya. Fatimiyah mewakili simbolisme otoritas politik Abbasiyah, Bizantium, filsafat dan Ismailiyah. Mereka menegaskan bahwa mereka adalah imam yang sebenarnya yakni imam keturunan Ali, berbeda dengan tradisi Syiah sebelumnya bahwa imam Syiah tersembunyi dan akan kembali sebagai al-Mahdi. Deklarasi Fatimiyah tentang imamah bahwa mereka adalah penerus siklus keenam dari para imam dan keyakinan datangnya al-Mahdi harus ditanggalkan. $^{27}$

Pada tahun 1169 Dinasti Fatimiyah mengalami kemunduran, Nur al-Din mengirim seorang jenderal bernama Sirkhuh dan kemenakannya yang bernama Saladin (Shalah al-din) untuk merebut kekuasaan atas Mesir. Pada tahun 1171 mereka memecat khalifah Fathimiyah yang terakhir dan mendirikan sebuah rezim Sunni. Selanjutnya sejarah Mesir dan Syiria disatukan hingga abad ke-19. Kehadiran Shalahuddi Al-Ayyubi di Mesir dapat menyatukan Syiria dan Mesopotamia menjadi sebuah kesatuan negara muslim. Tahun 1174 merebut Damaskus dan merebut Allepo tahun 1183 serta merebut Mosul pada tahun 1186, mengalahkan pasukan salib di Hittin (1197), dan mengakhiri pendudukan bangsa latin di Yerusalem. $^{28}$

\section{Era Safawiyah}

Pada tahun 1501 Ismail menduduki Tabriz dan menyatakan dirinya sebagai Syah Iran dan menaklukan seluruh wilayah Iran. Ketika imperium Usmaniyah yang menjadi rivalnya merebut Anatolia timur dan imperium Syaibaniyah mengambil alih transoxania sampai sejauh sungai Oxus, Ismail memperkokoh wilayah perbatasan dan sampai saat ini termasuk wilayah Iran.

Problem utama Safawiyah adalah mengkonsolidasikan otoritas keagamaan Syah dan kekuatan militer dan administrasi pemerintahan pusat terhadap sejumlah Uymaq Qizilbas yang secara nyata telah menaklukkan Iran. Di bawah kekuasaa Safawiyah, Iran diorganisir

\footnotetext{
${ }^{26}$ Joel L. Kraemer, Renaisans Islam (Bandung: Mizan, 2003), h. 106.

${ }^{27}$ Ira M. Lapidus, Sejarah Sosial Ummat Islam, h. 553.

${ }^{28}$ Ira M. Lapidus, Sejarah Sosial Ummat Islam, h. 554.
} 
menjadi sejumlah wilayah kepemimpinan uymaq yang berkuasa atas klan dan persekutuan kesukuan dan beberapa kota dan desa. ${ }^{29}$

Isu penting yang menarik pada masa Safawi adalah munculnya dua aliran Akhbari dan Ushuli dari kalangan Syiah. Kaum Akhbari berpendapat bahwa akhbar (hadis) yang berasal dari Nabi dan para imam merupakan sumber yang memadai untuk kehidupan keagamaan kaum muslimin. Sedangkan kaum ushuli menganggap argumentasi rasional penting dalam mengelaborasi ajaran-ajaran agama dengan tidak mengenyampingkan nash yang shahih. Akibatnya, berbeda dengan kaum akhbari, kaum ushuli memberikan kesempatan yang besar kepada ulama untuk menafsirkan dasar-dasar keyakinan Syiah dan dapat dijadikan panutan selama mereka hidup oleh pengikutnya. ${ }^{30}$

Pada akhirnya kaum ushuli dapat diterima dan mengalahkan kaum akhbari, sehingga menimbulkan muncul dan terbentuknya Marja al-Taqlid dan selanjutnya teori Wilayah alFaqih dari Mulla Ahmad Naraqi dan Syeh Muhammad Husein Naimi yang sama-sama menganggap bahwa ulama mempunyai hak prerogatif di bidang politik yang pada gilirannya dikembangkan oleh Ayatullah Khumeini. ${ }^{31}$

Safawiyah menjadikan Syiah Imamiyah sebagai agama resmi pemerintahan Iran dan mengeliminir pengikut sufi sebagaimana yang dilakukannya terhadap ulama Sunni dengan menyerap ide-ide filsafat dan gnostis dan pemujaan terhadap wali.

Krisis abad ke-18 mengantarkan kepada berakhirnya sejarah Iran pra modern yang berakhir dengan intervensi, penaklukan eropa dan pembentukan rezim kolonial. Konsolidasi ekonomi dan politik bangsa eropa telah didahului dengan kehancuran Safawiyah dan dengan liberalisasi ulama dan mewariskan sebuah kewenangan keagamaan Syiah yang kohesif, monolitik dan mandiri. ${ }^{32}$

\section{Revolusi Islam Iran}

Revolusi Iran disebut-sebut sebagai salah satu pemberontakan rakyat terbesar dalam sejarah umat Islam. Revolusi Islam Iran pada 1978-1979 merupakan contoh murni Islam politis dan Fundamentalisme Islam. Revolusi tersebut mengangkat banyak isu yang terkait dengan kebangkitan Islam kontemporer: keyakinan, kebudayaan, kekuasaan dan politik. Penekanan pada identitas bangsa, keaslian budaya, partisipasi politik dan keadilan sosial disertai pula dengan penolakan terhadap pembaratan, otoriterisme pemerintah, dan

\footnotetext{
${ }^{29}$ Ira M. Lapidus, Sejarah Sosial Ummat Islam, h. 443-444.

${ }^{30}$ Khoiruddin Nasution, Isu-isu Kontemporer Hukum Islam, h. 63-64.

${ }^{31}$ Khoiruddin Nasution, Isu-isu Kontemporer Hukum Islam (Yogyakarta: SUKA Press, 2007), h.64.

${ }^{32}$ Ira M. lapidus, Sejarah Sosial Ummat Islam (Jakarta: Rajagrafindo Persada, 1999), h. 466-467.
} 
pembagian kekayaan yang tidak merata. Iran di bawah Khumeini menjadi paradigma bagi Islam revolusioner atau radikal dan potensi penyebaran ancamannya dikhawatirkan oleh banyak pemerintahan di dunia muslim dan barat. ${ }^{33}$

Pasca revolusi 1979, perpolitikan di Iran tidak dapat terlepas dari kerangka fusi agama dan politik. Hal ini dapat dipisahkan dari kemenangan kaum ushuli yang memberikan kedudukan yang tinggi untuk ulama sehingga dapat mengembangkan konsep-konsep dasar politik Syiah yang terkristalkan dalam Imamah.

Disamping itu, ia merupakan hasil doktrin yang dilancarkan Khumeini sejak 1970-an yang menyatakan bahwa di saat ketidakhadiran Imam al-Muntadhar, seorang yang paling terpelajar, sahih, alim yang hidup di zamannya harus menjalankan roda pemerintahan atau dengan kata lain wilayah al-faqih-lah yang harus menggantikan imam ghaib. ${ }^{34}$

Setelah Khumeini berhasil menumbangkan Dinasti Pahlevi dan mendirikan Republik Islam Iran, hal tersebut dapat dilihat dari diktum Undang-undang dasar pada pasal 5 yang menyatakan bahwa kekuasaan atas negara dan umat dalam Republik Islam Iran selama Imam Mahdi masih ghaib (menghilang) ada di tangan ilmuwan agama (faqih) yang adil dan takwa, atau sejumlah ilmuwan agama (fuqaha). Tampaknya sebagai perpaduan dua konsepsi modern dan Imamiyah, maka sebagaimana negara lain, di Iran sekarang ini terdapat lembaga eksekutif, legislatif dan sebagainya. Di atas semua itu, harus ada seorang ilmuwan agama (faqih) yang memiliki kata akhir, menolak atau menyetujui keputusan yang diambil lembaga-lembaga tersebut. ${ }^{35}$ Meskipun secara teknis konstitusi menerima doktrin kedaulatan rakyat, hukum tuhan dan wakilnya, faqih menempati kedudukan tertinggi. Meskipun presiden yang dipilih secara langsung dan mewakili suara kedaulatan rakyat, faqih mewakili kedaulatan ilahi dari hukum Tuhan. ${ }^{36}$

Prinsip pemerintah oleh wilayah al-faqih dan keutamaan hukum Islam diabadikan dalam konstitusi Iran. Faqih akan dibantu oleh Dewan pelindung beranggotakan 12 ahli hukum Islam, enam orang dipilih Khumeini dan lainnya dipilih parlemen. ${ }^{37}$ Konstitusi itu menunjuk Khumeini sebagai faqih seumur hidup. Setelah ia wafat, jabatan itu diserahkan

${ }^{33}$ Jhon L. Esposito \& John O. Voll, Islam and Democracy, (terj), (Bandung: Mizan, 1999), h. 66

${ }^{34}$ Khoiruddin Nasution, Isu-isu Kontemporer Hukum Islam, h.65. Wilayah al-faqih dapat diartikan kekuasaan (otoritas) ilmuan agama, atau dapat dikatakan semacam otoritas politik faqih dalam mengatur urusan umat islam, yaitu pemimpin politik umat islam.

${ }^{35}$ Munawir Sadzali, Islam dan tata Negara (Jakarta: UI Press, 1993), h. 216.

${ }^{36}$ Jhon L. Esposito \& John O. Voll, Islam and Democracy, Terj. (Bandung: Mizan, 1999), h. 81.

${ }^{37}$ Dewan pelindung bertugas mengawasi pemilihan presiden dan parlemen, menafsirkan konstitusi dan memastikan kesesuaian antra setiap perundang-undangan dengan hukum dan konstitusi Islam. Wewenangnya termuat dalam konstitusi Iran pasal 96, yang menyatakan bahwa dewan pelindung mempunyai hak veto atas semua undang-undangyang lolos dari parlemen dan dinilai tidak islami. Selain itu, dibentuk pula dewan pengadilan tertinggi yang didominasi oleh para mujtahid. 
kepada seorang penerus yang memenuhi persyaratan atau suatu dewan yang terdiri dari tiga hingga lima faqih. Faqih diberi wewenang sebagai pemimpin tertinggi agama, sebagai penafsir hukum Islam yang tertinggi, menunjuk dewan pelindung dan mengepalai pengadilan, militer dan pengawal revolusi, bertindak sebagai pengawas presiden, perdana menteri dan parlemen. ${ }^{38}$

\section{Pasca The Arab Spring}

Berlarut-larutnya konflik Sunni-Syiah menjadi fenomena yang selalu paling banyak memakan tempat dalam lembaran sejarah sosial umat Islam. Berbagai perang yang berkecamuk di kawasan Timur Tengah juga tidak lepas dari konflik dua aliran tersebut. Sebagai contoh adalah konflik bersenjata antara Irak dan Iran, Irak merepresentasikan kekuatan Sunni dan Iran adalah Syiah yang mengakibatkan tergulingnya rezim Saddam Hussein. $^{39}$

Konflik Syi'ah-Sunni yang berkepanjangan itu turut mewarnai dinamika politik di kawasan tersebut pasca The Arab Spring. Hal ini dapat di lihat dari prahara Suriah yang hingga kini belum selesai. Pada konflik Suriah, ada permainan asing yang memiliki pengaruh sangat besar. Dari konflik ini, ada pertarungan antara Amerika Serikat dan sekutunya yang mayoritas Negara Sunni dengan China dan Rusia yang selalu menggandeng Iran yang dikenal sebagai negara Syi'ah. Negara-negara Sunni pun berada di belakang Amerika, salah satunya adalah Arab Saudi. Sementara negara-negara Syi'ah berada di belakang China dan Rusia. Hubungan Arab Saudi dan Iran sudah sejak dulu memiliki masalah besar baik soal politik, strategis, maupun ideologis (Syi'ah dan Sunni). Mereka berebut pengaruh serta supremasi di Timur Tengah dan Teluk. Pada krisis Suriah sangatlah jelas: Iran mendukung rezim Bashar al-Assad yang Syi'ah. Sedangkan Arab Saudi mendukung kelompok oposisi yang mayoritas Sunni. Kepemilikan Iran akan nuklir juga menjadi persoalan bagi Arab Saudi. Arab Saudi sangat tidak menginginkan posisinya sebagai primus inter pares yang terkemuka di antara sesama negara-negara Muslim disaingi oleh Iran (Kompas, 11/12/2013).

Berita terbaru terkait dengan sentimen Syi'ah-Sunni antarnegara adalah ketika Kepala Inteligen Arab Saudi Pangeran Bandar bin Sultan, negara 90\% Sunni, diam-diam bertemu dengan kepala badan inteligen Israel di Genewa Swiss. Pertemuan ini berlangsung pada tanggal 27 November 2013, tidak lama setelah pertemuan Iran dan P5+1 (AS, Rusia, China, Inggris, Perancis, dan German). Pertemuan badan intelijen kedua negara karena

\footnotetext{
${ }^{38}$ Jhon L. Esposito \& John O. Voll, Islam and Democracy, h. 82-83.

${ }^{39}$ Zainal Abidin, Imamah dan implikasinya dalam kehidupan Sosial, h. 197.
} 
kekecewaan Negara Wahabi itu dengan hasil dari pertemuan di Genewa yang dilihat mengunt ungkan Iran terkait dengan program nuklirnya (Kompas, 11/12/2013). ${ }^{40}$

Akar masalah konflik Sunni-Syiah saat ini sebenarnya lebih karena masih susahnya mencari titik temu dari berbagai perbedaan yang ada. Namun demikian, celah rekonsiliasi dan perdamaian tetap selalu terbuka lebar, apalagi jika dilihat internal Sunni dan Syiah kontemporer yang menunjukkan tren dinamika positif. Pada internal kedua kelompok ini terdapat faksi-faksi yang senantiasa mencoba menerobos sekat-sekat pembatas Sunni-Syiah. Internal Syiah bisa diwakili oleh faksi Zaidiyah yang dikenal sangat moderat dan kompromistik, sedangkan Sunni dapat diwakili oleh Indonesia, dalam skala negara. ${ }^{41}$ Walaupun di Indonesia terdapat penolakan terhadap Syiah sangat keras dan semangat sektarianisme agama sangat kental dan berkembang.

Indonesia yang sudah lama membangun wacana toleransi dan pluralisme tidak lepas dari dampak prahara yang belum berujung di Timur Tengah pasca-The Arab Spring. Sebagaimana telah dijelaskan bahwa ada sentimen Syi'ah-Sunni yang mewarnai konflik politik di negara-negara Timur Tengah pasca The Arab Spring, sentimen itu adalah sentimen mazhab Syi'ah-Sunni yang memiliki akar sejarah yang panjang.

\section{PENUTUP}

Berdasarkan uraian di atas, maka dapat disimpulkan bahwa apa yang terjadi antara aliran Sunni dan Syiah dimulai pasca meninggalnya Nabi Muhammad SAW. sampai sekarang bahwa telah terjadi sebuah konflik yang berkepanjangan yang dilatar belakangi oleh konflik politik, konflik ideologi, konflik paradigma dan pemikiran, yang menjadi faktor penghambat upaya rekonsiliasi, mengingat adanya peristiwa masa lampau yang sangat menyakitkan antara dua aliran tersebut.

Bagi Syiah, kisah diskriminasi yang dialami oleh Ali bin Abi Thalib hingga tragedi Karbala dengan terbunuhnya Husein, cucu Rasulullah dan kisah kepedihan Ahlul Bait menjadi ingatan sosial yang sangat menyakitkan. Bagi Sunni, penghinaan, cacian, makian dan pengkafiran yang ditujukan kepada para Sahabat utama Abubakar, Umar, Utsman dan Istri Rasulullah, Aisyah Al-Kubra, menjadi sebab disharmonisasi hubungan antara Sunni dan Syiah dan hubungan antara negara-negara timur tengah hingga kini.

Selain menjadi sebuah konflik, pertentangan antara Sunni yang dipelopori oleh Saudi Arabia dan Syiah oleh Iran memantik persaingan global antara kedua negara tersebut. Kedua negara tersebut masing-masing berambisi untuk menjadi super power di Timur Tengah dan berebut pengaruh serta supremasi di Timur Tengah dan Teluk.

\footnotetext{
${ }^{40}$ Ahmad Sahide, Konflik Syi'ah-Sunni Pasca-The Arab Spring, Jurnal Kawistara, 2013, vol 3 No. 3.

${ }^{41}$ Zainal Abidin, Imamah dan implikasinya dalam kehidupan Sosial, h.198.
} 


\section{DAFTAR PUSTAKA}

Ahmad Sahide. Konflik Syi'ah-Sunni Pasca-The Arab Spring, Jurnal Kawistara, 2013, Vol 3 No. 3.

Allamah MH. Thabaththabavi. Shiite Islam. Terj. Jakarta: Pustaka Utama Grafiti. 1989.

Asrar Mabrur Faza. Syiah dalam Kitab Sunni. Medan: Perdana Publishing. 2015.

Gonzalez, Nathan. The Sunni-Shia Conflict: Understanding Sectarian Violence in The Middle East. USA: Nortia Press. 1979.

Ira M. Lapidus. Sejarah Sosial Ummat Islam. Jakarta: Rajagrafindo Persada. 1999.

Khoiruddin Nasution. Isu-isu Kontemporer Hukum Islam. Yogyakarta: SUKA Press. 2007.

Kraemer, Joel L. Renaisans Islam. Bandung: Mizan. 2003.

Muhammad Abu Zahrah. Aliran Politik dan Aqidah dalam Islam Terj. Jakarta: Gaya Media Pratama. 2011.

Munawir Sadzali. Islam dan Tata Negara. Jakarta: UI Press. 1993.

Quraish Shihab. Sunnah-Syiah, Bergandengan Tangan, Mungkinkah? Kajian atas Konsep Ajaran dan Pemikiran. Jakarta: Lentera Hati. 2007.

Watt, W. Montgomery. The Majesty That was Islam. Terj. Yogyakarta: Tiara Wacana Yogya. 1990.

Zainal Abidin. Imamah dan Implikasinya dalam Kehidupan Sosial. Jakarta: Balitbang Kemenag RI. 2012. 